\title{
On Understanding Syrian Diasporic Identities through a Selection of Syrian Literary Works
}

\author{
Ghada Alatrash \\ Mount Royal University \\ galatrash@mtroyal.ca \\ Najat Abed Alsamad \\ drnajat.a.s@hotmail.com
}

\begin{abstract}
As of late August 2018, a total of 58,600 Syrian refugees have arrived in Canada (Government of Canada, 2019). The Syrian Diaspora today is a complex topic that speaks to issues of dislocation, displacement, loss, exile, identity, a desire for belonging, and resilience. The aim of this paper is to offer a better understanding of the Syrian peoples who have become, within the past four years, part of our Canadian citizenry, local communities, and members of our schools and workforce. By engaging the voices of Syrians through their literary works, this essay seeks to challenge some of the ontological and epistemological underpinnings that have historically defined Syrians and to offer alternate ways in which we may better know and understand what it means to be Syrian today. Historically Syrians have written and spoken about exile in their literature, long before the the Syrian war began in March of 2011. To deliver a sense of Syrian identities, a selected number of pre-Syrian-war writers and poets are engaged in this essay, including Nizar Kabbani, Muhammad al-Maghut, Zakaria Tamer, Mamduh Adwan, Adonis and Nasib Arida; furthermore, to capture a glimpse of a post-war sentiment, the voice of Syrian novelist Najat Abdul Samad, whose work was written from within the national borders of a wartorn Syria, is brought into the discussion.
\end{abstract}

\section{Introduction}

"'Syria has become the great tragedy of this century - a disgraceful humanitarian calamity with suffering and displacement unparalleled in recent history,' said Antonio Guterres, head of the UN High Commission for Refugees" (Watt, Blair, \& Sherlock, 2013). In October of 2015 during Canada's Federal Election campaigns, the Government of Canada "committed to resettling 25,000 Syrian refugees by February 29, 2016." As of late August 2018, a total of 58,600 Syrian refugees have arrived in Canada (Immigration, Refugees, and Citizenship Canada, 2018). The Syrian Diaspora today is a complex topic that speaks to issues of dislocation, displacement, loss, exile, resilience and a desire for belonging. The aim of this paper is to offer a better understanding of the Syrian subjects who have become, within the past five years, part of our Canadian citizenry, local communities, and members of our workforce and schools. As we (educators, employees, community organizations, policy makers) look for ways to develop educational strategies and policies that may better facilitate the integration process for newly arrived Syrian refugees, we suggest it is important to also understand their history as well as their human condition and their lived realities and experiences. 
Given the newness of the movement of the peoples of the Syrian Diaspora whose arrival to Canada was first marked on November 4, 2015 (Citizenship and Immigration Canada, 2017), we have faced the limitation of the scarcity of literature written by the displaced Syrian peoples. However, historically Syrians have always written and spoken about exile in their literature, long before the revolution, or, in our opinion, this destructive war began in March of 2011. To deliver a sense of Syrian identities and their experience, we bring into this discussion only a handful of the many voices of pre-Syrian-war writers and poets including Nizar Kabbani, Muhammad alMaghut, Zakaria Tamer, Mamduh Adwan, Adonis and Nasib Arida. What we have selected of Syrian works in this paper speaks to two different topics: political dissent and the longing for return to a homeland - a homeland they left behind in search of the basic need to making a living and to attain a life of dignity and human rights. Furthermore, to capture a glimpse of a post-war written sentiment, we engage the voice of Syrian Novelist Najat Abed Alsamad whose work was written from within the national borders of a war-torn Syria (It is important to note here that we will engage the works of one of the authors of this paper, Najat Abed Alsamad, to present our thoughts and analysis of the Syrian identity as she lived and wrote from within a war-torn Syria). Again, this essay offers only a limited selection of the works of many Syrian writers and poets who have spoken what it means to live the experience of a Syrian citizen, and hence our selections of Syrian works are far from complete.

\title{
Locating Theoretical Framework: Edward Said's Orientalism
}

\author{
"Is it true ladies and gentlemen that the earth of man is for all human beings." \\ (Darwish, 2013, p. 13)
}

"No race possesses the monopoly of beauty, of intelligence, of force, and there is a place for all at the rendez-vous of victory." (Césaire, 1995)

To begin, we suggest that in order to come to better understand the Syrian identity, we ought to first consider what underpins our epistemological and ontological stances and critically reflect on the assumptions that we may hold on this topic. To try and arrive at an understanding, we suggest broaching the Syrian subject by first thinking through an anti-Orientalist, anti-colonial framework. We want to think about the ontological underpinnings of the Arab/Middle Eastern subject as historically presented within the framework of colonialism, and to challenge the underlying assumptions and ways of knowing that have been presented about the Arab/Middle Eastern subject, ones laden with political motives and entangled in a web of Euro-centric representations, and ones that have engendered a great deal of misunderstanding and misrepresentations.

Edward Said's (1979) Orientalism offers tremendous insight on the Western (British French, and later American) production of the "Oriental" subject (the Arab living in places of Asia, the Middle East, and North Africa) in which "Orientalism expresses and represents that part culturally and even ideologically as a mode of discourse with supporting institutions, vocabulary, scholarship, imaginary, doctrines, and even colonial bureaucracies and colonial styles... Orientalism is a style of thought based upon an ontological and epistemological distinction between 'the Orient' and (most of the time) 'the occident'" (p. 2). Before we continue to engage Said's notion on Orientalism in this essay, we would like to share with our readers that 
we were recently brought to critically consider how the word "Oriental" may be offensive to some. We are always grateful for this sort of critique and we mindfully and critically engage this term in this essay to particularly highlight and disrupt the ongoing colonialism in East/West relations, and to challenge its troubling colonial productions and misrepresentations. We would also like to point out that we are acutely mindful of the fact that the West (Europe, the U.S. and Canada) is made up of a very heterogeneous society that should not be summed up as a homogeneous entity, and is represented by a multitude of epistemological and ontological stances; otherwise, we would also be engaging an unfair and misleading representation of the West. For, as Treacher (2003) discusses,

The terms the West, Islam, Arab region, and America obfuscate more than they reveal. These nations terms/states obscure complexity, flatten differences within and across nations, and risk obliterating the possibility of locating differences as well as similarities between Islamic societies and the West. (p. 59)

In his Orientalism, Said (1979) further goes on to point out that "a large mass of writers, among whom are poets, novelists, philosophers, political theorists, economists, and imperial administrators, have accepted the basic distinction between East and West as the starting point for elaborate theories, epics, novels, social descriptions, and political accounts concerning the Orient, its people, customs, 'mind,' destiny, and so on" (p. 2-3). Marlon Simmons (2012) points to the importance of reminding ourselves of how "this knowledge comes to reside within publication houses, [and] to remember what is deemed knowledge and how this knowledge comes to be positioned/classified hierarchically through publications, keeping in mind that antiracism/anti-colonial knowledge is augured in and through the human experience" (p. 61). Along these lines, Lincoln and Guba (2000) write:

... we stand at the threshold of a history marked by multivocality, contested meanings, paradigmatic controversies, and new textual forms. At some distance down this conjectural path, when its history is written, we will find that this has been the era of emancipation: emancipation from what Hannah Arendt calls "the coerciveness of Truth," emancipation from hearing only the voices of Western Europe, emancipation from generations of silence, and emancipation from seeing the world in one color. (p. 185)

More than ever before, we believe in the critical need for disrupting a tenacious production of knowledge on the "Orient", one "that is based on the Orient's special place in European experience" (Said, 1979, p. 1) where the "Orient" is always presented as an Other of a difference. We ought to look at those representations and "events with complex historical processes that are difficult to sum up in words, those with technological mutations, those which include social transformations, those that locate themselves within political institutions, those projects of rationalization of knowledge and practices" (Foucault, 2007, p. 111).

In his essay, "The Politics of Knowledge," Said (2002) speaks of the importance of reintegrating "people and cultures, once confined and reduced to peripheral status, with the rest of the human 
race... By linking works to each other we bring them out of the neglect and secondariness to which for all kinds of political and ideological reasons they had previously been condemned" (pp. 379-382). He continues, "we are still in the era of large narratives, of horrendous cultural clashes, and of appalling destructive war-as witness the recent conflagration in the Gulf - and to say that we are against theory, or beyond literature, is to be blind and trivial" (Said, 2002, p. 383). Today, decades later, the clashes, the wars, and the destruction continue, and have only gotten worse. Said's experience of living as an Arab in the West, specifically in the United States of America, poignantly contextualizes an Arab's struggle to be understood in the West. He writes,

The life of an Arab Palestinian in the West, particularly in America, is disheartening... There exists here an almost unanimous consensus that politically he does not exist, and when it is allowed that he does, it is either a nuisance or as an Oriental. The web of racism, cultural stereotypes, political imperialism, dehumanizing ideology holding in the Arab or the Muslim is very strong indeed, and it is the web which every Palestinian has come to feel as his uniquely punishing destiny... The nexus of knowledge and power creating 'the Oriental' and in a sense obliterating him as a human being ... (p. 27)

Indeed, it is often the case that relationships between the East and the West are based on power, woven in a very complex web of hegemonic, colonial, political, imperialistic frameworks. To undo the mis-representations would indeed be an overwhelming task but here it becomes of critical importance to offer a re-presentation and to invite a cultural position and a cultural reading by way of evoking individual accounts and personal narratives in order to fill in an "almost total absence of any cultural position making it possible either to identify with or dispassionately to discuss the Arabs or Islam" (Said, 1979, p. 27).

In this paper, we hope to present a counter-narrative and bring balance to the stories that have been historically written through a fixed colonial lens. In his Politics of Diaspora, Simmons (2012) points to the importance of Foucault's (1980) notion of the insurrection of subjugated knowledge and poses some critical questions with regards to the concept of "dismissed knowledge;" he asks, "how is qualitative research constituted through story, personal narratives, folklore and proverbs? That is, through bodies of knowledge placed tangentially to standardized educational philosophies? This also leads to the question, what body of knowledge constitutes research? Or, put it another way, how do we come to know a particular piece of writing as knowledge?" (p. 38). We believe that it is by triggering such questions that we are concomitantly disrupting the notion of knowledge being held as one truth and simultaneously giving way to originality and individuality.

Within the context of the Syrian Diaspora, it is important to work through the epistemological uncertainties on the Syrian diasporic subject and allow for their stories to constitute our knowledge by way of engaging their individual voices as oblique tangents that depart from a linear knowledge and as countervailing ways of knowing, when "histories are bringing a fixed homogenous reading onto the Diasporic body, for within these histories, heterogeneity is very much central to the experiences of the Diasporic subject" (Simmons, 2012, p. 141). Simmons 
adds, "the Diaspora is constituted through different bodies, different identities, different experiences, that the Diaspora is constituted through difference" (pp. 145-146). Simmons' experience as a Diasporic identity in the West reminds me as an Arab that more commonalities exist amongst humans located in different diasporic bodies, that the task ahead of us is indeed tangled and complex, and that we, as Othered, are working towards the same task "of freeing up the Diasporic subject from the historical essentialized narratives of colonialism, which inevitably opens possibilities for the human condition," so that we may ultimately come to make sense of what it means for the Other to be human (pp. 104-105).

We suggest that in order to think against the forces of hegemonic ways of knowing, we must come to engage ethnic and local voices (of exiles, of refugees, and of Syrians within the context of the Syrian Diaspora) so they can re-tell the narratives that have been repeatedly written about them through a fixed colonial lens. It is these sorts of personal and lived accounts that will help undo a dominant hegemonic, homogenous Western narrative by shedding light on the fact that the Eastern/Middle-Eastern/Arab/Syrian identity is made up of multiple subjectivities in and of themselves. We deeply believe that the dominant epistemologies have yielded great harm, and we hope that the literature provided throughout this paper will help challenge a colonially inscribed epistemology and open different possibilities and ways of thinking of the Syrian subject of our research by way of a "cultural verstehen of Others" or an empathetic understanding (Chang, 2008).

\section{On the Syrian Identity}

Who are we speaking about when we speak of the Syrian Diaspora? How do we come to make sense of their lived experience of having lost a home and a homeland? What cultural similarities, and what differences, do they bring with them? What are the ontological and epistemological underpinnings that have defined our body of knowledge on the Syrian peoples? Who are the subjects of the Syrian Diaspora? The answer simply is that there is not one answer as we hope to demonstrate in this section of our paper. Syrians come from a heterogeneous Syrian society and belong to diverse socioeconomic, religious and educational backgrounds. Perhaps the shared similarity amongst the Syrian Diaspora in Canada is that it is made up of humans who have been uprooted from their homelands and forced to leave. They are tired and pained bodies. As an Arab Diasporic subject, Palestinian Mahmoud Darwish (2013) has written about his Diasporic experience as part of the Palestinian Diaspora:

Earth is pressing against us, trapping us in the final passage.

To pass through, we pull off our limbs.

Earth is squeezing us. If only we were its wheat, we might die and yet live.

... Where should we go after the last border? Where should birds fly after the last sky? (p. 9)

Like the Palestinians before them, earth is also closing in on Syrians today, leaving them with no other choice and with no place for escape. As a Syrian-Arab living in the West for over thirty years, we have continued to struggle with the endless misrepresentations that have encapsulated all Middle Easterners/Arabs/Muslims/Non-Muslims into a binary of Us (the West) and them (the 
East), where, as in the words of Said (1980),

So far as the United States seems to be concerned, it is only a slight overstatement to say that Moslems and Arabs are essentially seen as either oil suppliers or potential terrorists. Very little of the detail, the human density, the passion of Arab-Moslem life has entered the awareness of even those people whose profession it is to report the Arab world. What we have, instead, is a series of crude, essentialized caricatures of the Islamic world, presented in such a way as to make that world vulnerable to military aggression. (para. 11)

We believe that the need for a counter narrative is dire, one that disrupts the notion of a homogenous and singular understanding of what is summed up as Arab identity for the Arab identity is made up of twenty-two heterogeneous countries spread across North-Eastern Africa, the Middle East, and the Arab Gulf Region. This heterogeneity does not only exist between the different countries but also within the national borders of each of those countries which are made up of hundreds of millions of different human identities who come from a myriad of religious affiliations, socioeconomic, educational, and historical backgrounds and political allegiances. On the Syrian identity, Professor Mohja Kahf (2001) of the University of Arkansas further explains,

Syria has not, historically speaking, had a great deal of ethnic homogeneity; a vast number of ethnic groups have comprised this region's population. Syria has also been a place where many religions and religious sects have been born and have flourished, skirmished, and lived as neighbors. The majority of the people of Syria today are Arab; a Syrian may also be Kurdish, Armenian, Circassian, Chechen, Daghestani, Turkish, Jewish, Assyrian. Sunni Islam is the majority religion, and Syrians are also Christian (Greek Orthodox, Catholic, Maronite, Church of the East, and others), Druze, Ismaili, Alawi, and Jewish. (pp. 225-226)

Today, the Syrian war has added to the complexity of what it means to be Syrian. Historically, Syrians have always been divided in an "ideological battle between Arab nationalism endorsed by the Baath Regime [of the Assad ruling family] and Islamism in the seventies and eighties", a binary through which Syrian identity is positioned (Díaz, 2016, p. 86). However, more so today than ever before and since the Arab Spring in 2011, Syrians are deeply divided in their political views and opinions about the war in Syria. Syrians today stand on polar sides of this debate, to the point that they no longer recognize one flag for their shared country. Since the revolution, two Syrian flags have been waived by divided Syrians - one that represents allegiance to the incumbent government led by Bashar al-Assad and the Ba'th Party and "the green, white and black flag of the former Syrian Republic, which existed before the Baath Party and the Assad family came to power [which] has been officially adopted by the main opposition coalition, the Syrian National Council, and the Free Syrian Army, an armed rebel group that has vowed to overthrow Mr. Assad by force" (Mahmud, 2012, para. 1-2). Ever since the war, the Syrian flag is an immediate indication of whether a Syrian citizen/refugee is pro-regime or anti-regime, and it ultimately defines a Syrian's ontological and epistemological stances based on very different 
conceptualizations of what they believe to be the truth; today, the Syrian flag has become an identity card for Syrians.

There are also Syrians, like novelist Abed Alsamad, who are simply no longer concerned with matters of "truth," and are only looking for ways to live or stay alive. In an appeal to humanity, Abed Alsamad writes,

I don't care about being pro or anti [regime]. All I want is for my only brother to find food. He is seven years-old and is as thin as a shadow and has not been able to go to school for a day. My fourteen-year-old sister is also about to collapse from lack of food. And we, the older daughters, have been displaced, each with her husband in a different country. (Abed Alsamad, 2016, p. 111)

The opposing voices of Syrians today deeply embody the notion of multiple truths. Each voice, whether pro, anti, or simply doesn't care to be either, becomes an added subjective thread to an extended epistemology on our understanding of the Syrian conflict today. As explained in the words of Díaz (2016), "in any conflict, the concept of identity comes to the forefront as an element of cohesion and differentiation from others; however, such differentiation becomes more difficult when it comes to people claiming the same identity" (p. 85), as is the case with Syrian identity today, and as Simmons (2012) adds, "identity involves more than just naming the respective body. Identity concerns a myriad of historical processes of coming into being. Identity involves positionality, location, constitutive of agency. Identity is not evenly formed. Identity is always already a work in progress, and unfinished and incomplete in its being" (p. 98).

\section{Pre-War Syrian Literature}

As mentioned earlier in this paper, a limitation to our understanding of the Syrian Diasporic and displaced subject today is that the post-war literature on the Syrian Diaspora today is scarce and is new to research. But Syrians have always written and spoken about exile in their literature. The names of Syrian authors, poets and scholars are abundant. Their narratives, like in other native local narratives, speak to a national substance and sentiment. For the purpose of this paper, we have selected excerpts that speak to two different topics: political dissent and the longing for return to a homeland. Once again, we find it important to emphasize to the reader our limitation of not being able to cover the mass of materials written by Syrians on their experiences of displacement, Syrians who were forced out of their homeland for a myriad of reasons ranging from the basic need to find work to being subjects of political sentences that expelled them away from Syria's national borders; hence, our selection is far from a complete account of the multitude of Syrian narratives on political dissent and displacement.

In the political realm, we hope that the handful of narratives we have selected can deliver to the reader a sense of the Syrian sentiment and of the conditions under which the Syrian Diaspora lived prior to being displaced. For long, Syrians have voiced their pleas and anger to their government, protesting the state of their living conditions under the rule of a stern political dictatorship. In 2001, ten years before the current war, Kahf (2001) wrote an article titled "The silence of contemporary Syrian literature." In her article, she poses an important question, 
... despite the suspicious eye of the government on them, these sorts of initiatives from below are increasing. Perhaps a new spirit is moving in the land. Will Syrians begin to converse in these new cultural spaces, and will they be unafraid to let their voices rise? Or, like Rappacini's daughter in Hawthorne's tale, has the Syrian body become so accustomed to the poison -- silence -- that the antidote would kill? (p. 236)

Today, more than fifteen years after, we believe that an answer to Kahf's question is: Yes, the Syrian people have indeed shed the wall of fear and they have risen, but the consequences have been disastrous as Syria lies in ruins today while the blood bath continues.

Of what has been written prior to the Syrian war, we bring into our research the important and major voices of Nizar Kabbani (1923-1998), a poet known for both his poetry of love as well as his defiant poems of political protest; Muhammad al-Mahgut (b. 1934-2006), political prose poem and short story writer whose famous work I will betray my homeland is an embodiment of the struggle of the Syrian citizen, and as importantly, the Arab citizen; Zakaria Tamer (b. 1931), an influential master of Arabic short stories and political satirist; Mamduh Adwan (b. 19412004), a poet and a dramatist who was "ferocious in his denunciation of corruption and despotism" (Clark, 2005, para. 5); Adonis (b. 1930), a prolific poet once imprisoned for his political activities in 1955 and who left for Lebanon thereafter; Nasib Arida (1887-1946) who wrote from the Arab mahjar [Diaspora] in New York in a continuous nostalgic longing for return to his homeland. Some of the other figures that we ought to mention as notable Syrian names, aside from those who are discussed in this paper are neoclassical-school poet Badawi al-Jabal (1907-81), twentieth century prominent Umar Abu Risha (1910-1990), Kurdish-Syrian poet and novelist Salim Barakat (1950), poet Nuri al-Jarah (1956), novelist and politician Abdal-Salam alUjayli (1918-2006), poet and short story writer Saeed Horaniyeh (1929-1994), realist novelist Faris Zarzur (1929-2006), novelist and short story writer George Salem (1933-1976), novelist, poet and journalist Ghada Samman (1942), social realist novelist Hanna Mina (1924-2018), short story writer and noveliliest Ulfat al-Idilbi (1912-2007), short story writer and novelist Haidar Haidar (1936), novelist and poet Colette Khoury (1937), novelist Samar Attar (1945), poet Wasfi Qurunfli (1911-1972), poet Ali Aljundi (1928-2009), Hani al-Rahib (1939-2000), poet and journalist Fayez Khdour (1941), poet Ayman Abu Sha'ar (1946), novelist Mamdouh Azzam (1950), novelist Khalid Khalifah (1946), novelist Najat Abed Alsamad (1967) amongst a list of others. These are writers whose narratives embody a heterogonous representation of the Syrian identity and speak to different themes and perspectives on the Syrian lived experience.

In 1963, the Ba'th Party took rule of Syria. Hafez al-Assad was part of this party and became president of Syria in 1971. In 2000, he was succeeded by his son, Bashar al-Assad, who continues to be the incumbent President of a war-torn Syria today. The Ba'th regime has always been known for its censorship, where, as explained by Kahf (2001),

Article $4 b$ of the state of emergency [of Syria's Emergency Law] straightforwardly permits the state 'to control newspapers, books, broadcasting, advertising, and visual arts -- in other words, all forms

Journal of Contemporary Issues in Education, 2020, 15(2), pp. 3-22. 
of expression and announcements before publication. It may also stop, confiscate, and destroy any work deemed to threaten state security, or close down offices and places of printing' (Human Rights Watch,

109). (p. 228)

Also as explained by Kahf (2001), "Paradoxically, the heaviness of censorship in Syria spurs some writers to new levels of creative development," although often at a heavy price as was the case "in 1985, [where] novelist Hani al-Rahib was arrested, not for anything he wrote, but just for saying at a Writers Union lecture in Damascus that individual freedoms were greater in Egypt than in Syria ... [he was] fired from his job at the University of Damascus, not allowed to travel out of the country for two years, and beaten by the state police" (p. 230). Kahf adds, "Among all Arab cultures, Syrian culture has become the one most associated with the posture of paranoia stemming from a realistic fear of a police state with a vast surveillance apparatus and great demands of public shows of allegiance" (p. 233).

Nizar Kabbani's works are famous for their explicit political dissent. In his collection "Works that are frowned upon," Kabbani writes a poem titled "A top-secret report from the countries of Supress-stan" where "stan" is the Urdu or Persian for place, land, or country. In this poem, the poet's words embody an explosion of sentiments suffocated by political suppression. He writes,

Do you know who I am?

I am a citizen of the nation of "Supress-stan"

... and most important of its exports

are leather bags

made of human skin

... a citizen whose utmost dream

is to rise to the rank of an animal. [Translated by Ghada Alatrash]

(Kabbani, 1992, pp. 29-31)

Kabbani felt oppressed, felt like an animal not a human, but was not afraid to write and to stand against the injustices. He is courageous and he is defiant. His writing was an act of resistance. This dialectic relationship between oppressor and oppressed ought to play a significant role in coming to understand the courageous, defiant and resistant spirit of Syrian identities, and as importantly, it is one that ought to evoke an empathetic understanding of an oppressed peoples whose dissent against the political regime found them in a painful state of displacement today. In another widely known poem titled "Balqis" (the name of Kabbani's wife), Kabbani mourns his massacred wife and writes, "They've killed you, Balqis / What kind of an Arab world is this / . . one that chokes canaries?" (Kabbani as cited in Kahf, 2000, para. 50). Then the poet's sentiments are quickly transformed into anger as he vows to take revenge and writes,

I swear by your eyes

that draw millions of planets into them

that I shall speak infamies

about the Arabs

I shall say: Our chastity is harlotry

our piety is filth 
and I shall say: Our struggle is a lie

and there is no difference

between our politics

and prostitution. (Kabbani as cited in Kahf, 2000, para. 51)

Here, the poet's words speak of a human heart mourning the loss of a beloved wife. The words are saturated with pain, a sentiment that springs from the intimate depths of human experiences and one that ought to be understood by every human heart on earth. They speak a language of human suffering voicing a plea for a desire to live like humans not as oppressed animals, and importantly, a sentiment that was also once experienced by many of today's people of the Syrian Diaspora, for as explained earlier by Professor Wendy Pearlman (2017), "they [the Syrian Diaspora] would prefer to live with safety and dignity in their own country if they could. But they cannot" (para. 3).

Muhammad al-Maghut's works voice deep political messages of dissent and resistance, where living under such oppressive reality becomes resistance in and of itself. I will betray my homeland: Ravings of terror and freedom is one of the works in which al-Maghut expresses his outright repulsion for the wretched living conditions endured by the Syrian/Arab citizen; his writings are cynical and often blended with bitterness and anger. al-Maghut's boldness also never ceases to amaze me - to announce that he will "betray" his homeland on the cover of his book is indeed a representation of a Syrian spirit who had come to no longer fear death. We have selected his poem "Roof" as a poignant representation of the Syrian/Arab sentiment in which the most complex of human emotions are transformed into fierce lines of defiance and criticism. He writes,

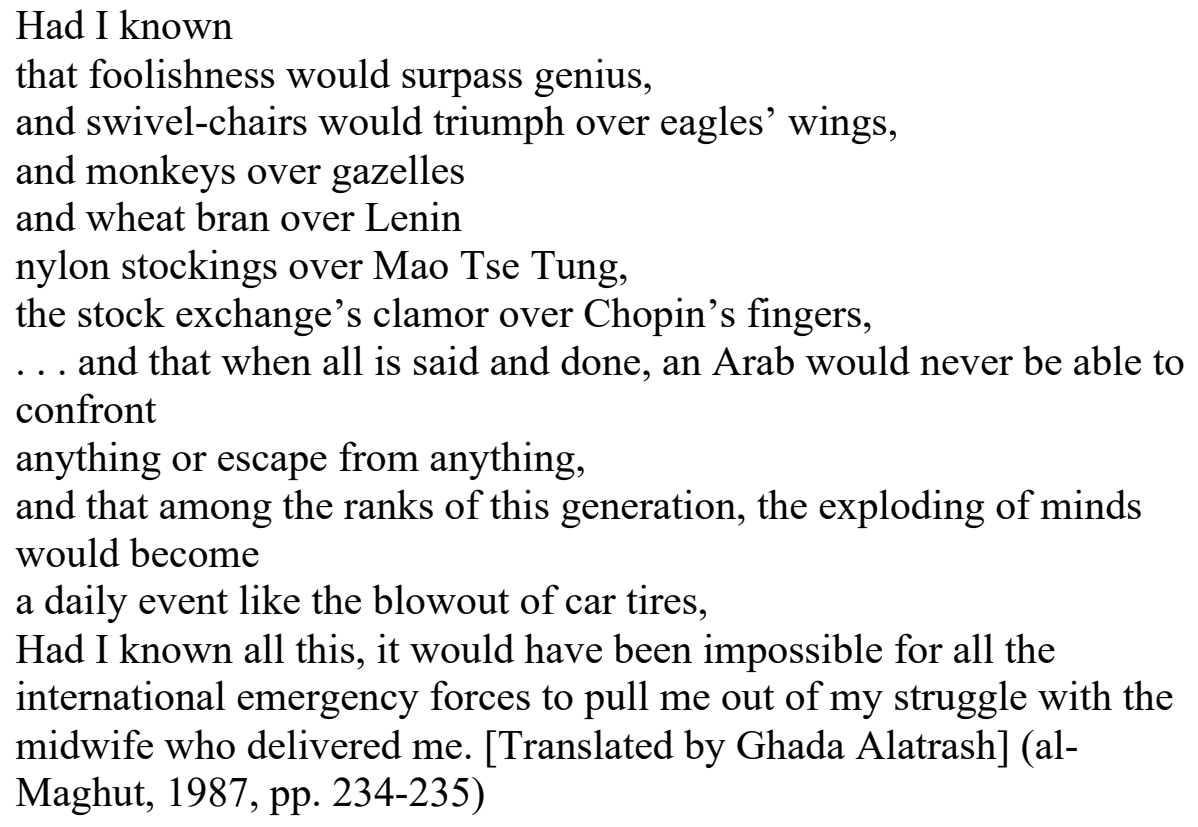

In this excerpt, the peoples of Syria (whose coat of arms is imprinted with an eagle), Russia (under Lenin's communism), China (under Mao Tse Tung's communist revolutionary leadership), and Poland (where Chopin's music becomes an embodiment of the Polish uprising) 
are all united in their lived experiences under oppressive political structures. They also become united in their revolutionary oppositions against the forces of oppression-a stark reminder of the commonalities in the lived human condition across national borders. al-Maghut continues,

But now that I have experienced all of this and have learned all these things, what am I to do?

If I write, I'll die of fear.

If I don't write, I'll die of hunger.

They say that climbing to the mountaintops requires some stooped backs, and so I stoop, not out of subjugation, but of exhaustion. (p. 235)

al-Maghut's language is interwoven with a dismal lived experience of an Arab citizen, and it is in and of itself revolutionary. Encoded in his message is a defiant outcry against unjust, wretched, petty and oppressive living conditions. He makes clear that in his country (the country that was also once home to the Syrian Diaspora) all roads lead to death, for whether or not he writes, he predicts that he will die. However, writing becomes a revolutionary act, a means to fulfilling a gnawing hunger, and an embodiment of Syrian courage and a resistant spirit in the face of death.

Another important defiant Syrian author known for his political dissent is Zakaria Tamer. Kahf (2001) writes on Tamer: "In story after unsettling story, terrible things happen, crimes are committed, but the bizarre, hallucinatory quality of the narrative numbs us, forces us to watch people go on acting normally in the midst of horror, as if nothing were wrong" (p. 233). In his story Tigers on the Tenth Day, Tamer tells of

"a trainer [who] uses hunger to make a wild caged tiger submit to the whip, and even, eventually, to like submitting to the whip, against the very nature of its being as a tiger [where the hungry tiger, after ten days, begins to eat grass against his inherently carnivorous nature]. The tiger is fully 'trained' by the end of the short, terse story: 'On the tenth day the trainer, the pupils, the tiger, and the cage disappeared; the tiger became a citizen and the cage a city"" (Kahf, 2001, p. 233).

The message conveyed in this story, by evoking animal figures, speaks to the destructive, and equally important, petty and miserable end of the subjugated human. Tamer alludes to how a subjugated human is deliberately "trained" and "numbed" into accepting an imprisoned reality "as if nothing were wrong." Within his story is a call to be awakened to a reality of horror that numbs the senses and the mind, and ultimately beguiles a subject into acquiescing to a miserable life-time imprisonment in a cage (a country). After the eruption of the Syrian war, an article written in 2012 on Syrian Zakaria Tamer offers a new dimension to his writing. We find the following excerpt especially relevant to our discussion on the Syrian Diaspora; it is titled "Who are you?" Tamer writes,

Who is the Syrian?

The Syrian is an unknown citizen, he did not become famous for

Journal of Contemporary Issues in Education, 2020, 15(2), pp. 3-22. 
having chosen death, prison, and endurance over suffering and selfabasement as the path to freedom. The Syrian is a citizen living outside Syria and a citizen living within its borders readying himself to leave as soon as he is able, and what unites Syrians inside and outside Syria is a loathing of tyrants and their regimes from A to $\mathrm{Z}$. (Hacker, 2012, para. 1)

When juxtaposed to "Tigers on the tenth day," we ought to note how Zakaria's post-war writing is transformed from implicit hints by way of evoking animal figures (a style noted in his writing) into bold accusations pointed at "tyrant and regimes from A to Z." In the latter excerpt, the voice of the poet embodies an evident sense of fearlessness representing a revolutionary Syrian spirit no longer threatened by "tyrants," a spirit that has chosen to walk the paths of imprisonment and death in search of freedom. Tamer's narrative speaks to a becoming and transforming Syrian identity. His language is resolute; it is a language that has emerged from the ashes, a language that was once subjugated and has now broken free from the chains of fear.

Syrian Mamdouh Adwan is another poet known for engaging his pre-war poetry to express defiance against what had become intolerable Syrian living conditions. In his poem "Misyaf" (named after the poet's hometown), Adwan writes,

We've learned to live on the least and each one has accepted to live as a body without a soul. Loneliness circulates in our blood flow. (Adwan, 2009) [Translated by Ghada Alatrash]

And in an excerpt from the same poem implicitly addressing the dictator who happens to be of the same Alawite religious sect as is the poet and claims to protect it, Adwan writes,

He [the dictator] sat to untie his bundle and he began to drop the faces of my beloved one by one in my heart: 'Here's a friend who had once disappeared in prison and this one died of oppression and this one wandered in exile and another lost in a war' ... we are strangers in our homeland without a home. (Adwan, 2009) [Translated by Ghada Alatrash]

Here, it is important to point to the fact that Syrians have always felt a sense of alienation and estrangement, living like strangers in a "homeland without a home." Syrians are peoples who have always yearned to belong, as humans, to their homeland. Syrian literature has often expressed a deep sense of suffering where a Syrian citizen has been depicted like "a body without a soul," and they have acted "as metaphors for everything that human beings aspire to" (Darwish, 2000, p. 29). Importantly, the discussed narratives represent a life once lived by many people of the Syrian Diaspora, a life of loneliness and oppression, and a life in which a Syrian national felt homeless even within the borders of a homeland. 
But what does it mean to not find belonging in one's own homeland? In 2009, Syrian author Najat Abed Alsamad wrote a novel titled Lands of Exile. In the first page of the book Abed Alsamad writes addressing her homeland of Syria, "Our pleas have become hoarse / Love us and put an end to our exile" (Alatrash, 2016, p. 126). Abed Alsamad's words yet again act as another voice for a national Syrian sentiment, an outcry of anguish addressed to a country whose children have been expelled to all corners of the world. Abed Alsamad's novel was also another pre-war work in which she wrote about the lands to which Syrians have been exiled in search of bread and opportunities; she tells of their lived experiences, ones deeply interwoven with feelings of estrangement, pain and longing to belong.

Yet despite all the pain and suffering, the humiliation and the anger, exiled Syrians continued to write love letters to their homeland. Syria remained to be their mother and their first beloved. For Syrians, there seems to be a clear distinction between Syria as a beloved mother(land) and Syria as an oppressive political regime. Kabbani lived in exile for many years, some of which were spent in Britain. While in Britain he wrote about Damascus in utter longing:

My voice rings out this time from Damascus.

It rings out from the house of my mother and father.

In Damascus, the geography of my body changes;

my blood cells become green

and my alphabet becomes green.

In Damascus, a new mouth sprouts from my mouth, a new voice sprouts from my voice;

and my fingers become a tribe of fingers.

... I return after sixty years

in search of my umbilical cord,

... I return to the womb in which I was formed

and to the first woman who taught me

the geography of love

and the geography of women.

I return after my pieces have been scattered

in all continents,

and my cough dispersed in all hotels;

for since my mother's laurel-soap scented bed sheets,

I have found no bed on which to sleep.

(Alatrash, 2016, pp. 6-7) [Translated by Ghada Alatrash]

Likewise, Syrian poet Adonis, an influential poet of the twentieth century who lived his career largely in Lebanon and France after suffering from political consequences, also wrote in desperate longing for Damascus:

When will we die, Damascus, when will we find ease?

And last night, in dream, Damascus,

I shaped a statue of clay.

In her white curves, I plantedyour history, Damascus,

and $I$ began in terror and in joy

Journal of Contemporary Issues in Education, 2020, 15(2), pp. 3-22. 
to fall like a quak on the hill of Jilliq.

I embraced her, stroked her and sang

mmm mmm crescent moon.

And I said, No, you'll remain in longing, Damascus

in my blood. (Adonis, 2010, p. 70)

Both poets speak to the deepest sense of longing and homesickness. They voice a sentiment that speaks to the painful lived experience within the estrangement of exile. The words in their poems are drawn from and constructed with memories of a homeland; they are words narrated by human hearts and speak of a human experience that goes beyond the confines of all other discourses. We find that these poems embody a relationship between the human mind and the human heart, between the past and the present, one that poignantly speaks to and offers new ways of understanding the experience of the Diasporic identity. Despite the most oppressive of lived condition, a motherland remained sacred in the eyes of the two poets.

Along the same lines, Syrian Nasib Arida (1887-1946) who was part of the Syrian American Diaspora (mahjar) in the U.S., wrote of his birth city Homs. Ironically, today Homs happens to be one of the cities most severely affected by the Syrian civil war where much of it has been destroyed by one side or another (regime or opposition). In 1905, Arida emigrated to New York and was also one of the founding members of the New York Pen League along with LebaneseAmerican Kahlil Gibran. Arida is known to have been "a poet of the dark side of life- his verse characterized by pain, tears and separation, by nostalgia for his country of birth, and by bewilderment" (Encyclopedia of Arabic Literature, 1998, p. 103). His poem on his home city of Homs is what we have selected for the discussion of this paper as an embodiment of what it means to live in exile, in the Diaspora. He once wrote,

Oh fate, it's been far too long from my homeland

... Take me back to Homs, even if stuffed in a coffin

and chant, "I've brought back someone who's gone astray."

And build my grave with black stones [basalt].

Oh you [Homs], neighbor of the Asi [river],

my hopes end in seeing you.

You are my desire and my yearning.

... Oh Homs of the black stones. (Arida, n.d.)

As we reflect on this poem and on what has become of the city of Homs today, we can only begin to imagine the magnitude of the heartbreak that would have been felt by the poet had he been alive today. Today, many residents of the city of Homs have become subjects of the Syrian Diaspora, displaced within and outside of Syrian borders. The poem was written long before the Syrian war, but it about a city that is home to the poet and to many displaced Syrians today, of the Asi River that runs through the city, of the black Basalt stones with which the older homes of the city were built. We have chosen two images to capture the feel of the city of Homs. The first photo (Demeter, 2014) captures the black-stone Basalt homes known to Homs, and the second photo (Eid, 2016) is one of several images published by the Huffington Post in 2016, five years after the eruption of the Syrian war. 


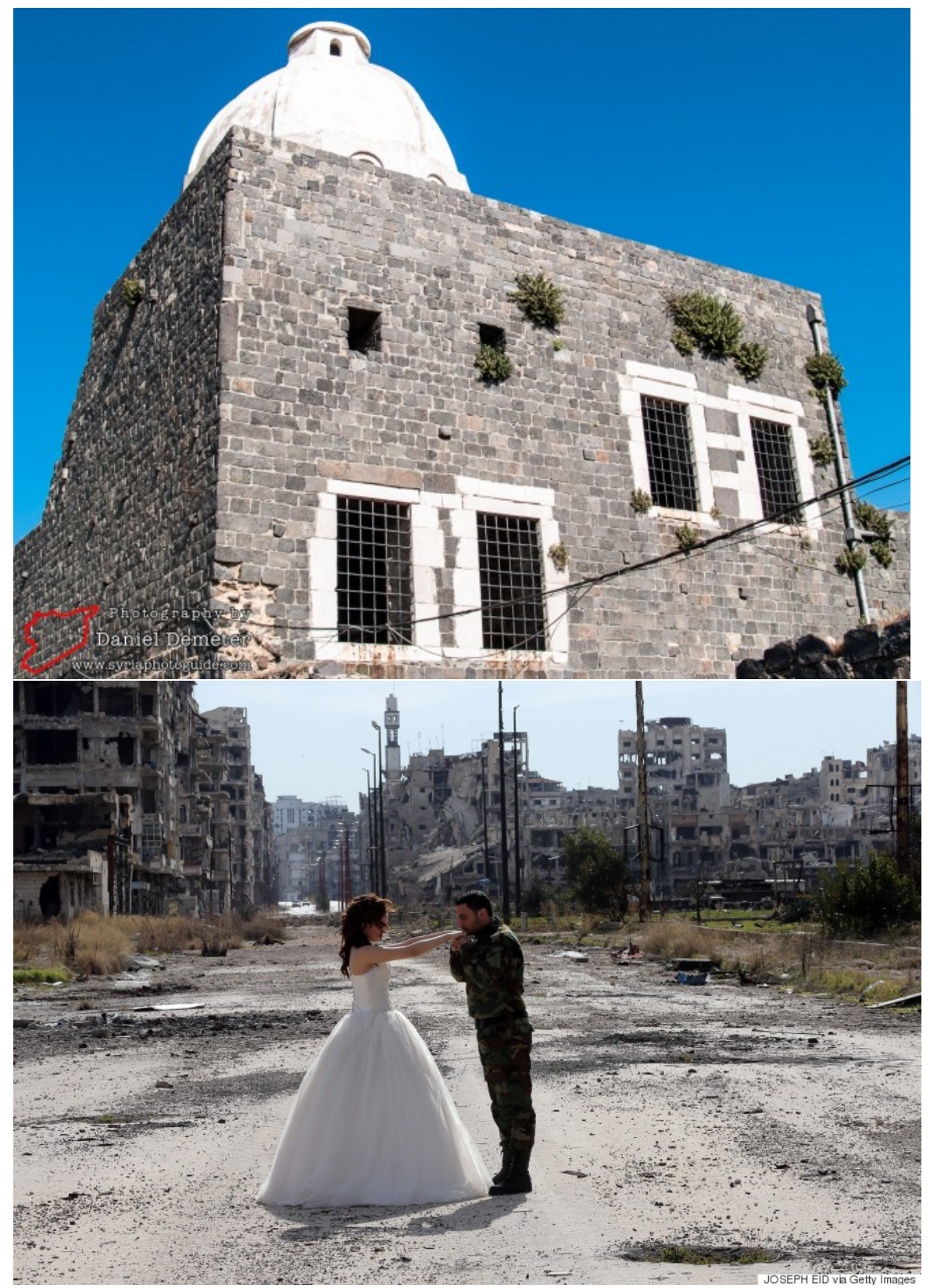

Once again, Homs happens to be home to many of the people of the Syrian Diaspora, and I deeply believe that it remains to be the place where many Syrian hearts continue to live apart from their Diasporized bodies.

We hope that the selected narratives in this section of the paper may have delivered to the reader a deeper understanding of the Syrian sentiment and of the conditions under which the Syrian Diaspora once lived prior to being displaced, and have come to trouble and disrupt what had been disseminated of Orientalist and colonial narratives on the Arab subject. What we have selected of Syrian works in this paper speaks to two different topics: political dissent and the longing for return to a homeland. 


\section{Post-War Syrian Literature}

From within a war-torn Syria, Najat Abed Alsamad's voice is one of the post-war prolific voices published in newspapers and magazines across the Arab world. She writes, "Then, You are Alive!":

You are alive then!

... You may be wounded or ill-fated or disabled or bereaved or abandoned, but you are alive, and you are still in your country, in your house specifically, gazing at the straw plate that you had inherited from your grandmother as it still hung in its place on the wall and was not stolen nor dragged by a shell to the hills of heaps that have become the topography of your country. You are embarrassed but thankful for being completely safe in a mass destruction called war, while you realize that your safety implies the death of others whom you do not know, whose hands could have written these words on your behalf.

... You carry on with your mind and your pick, and you continue your journey into the remaining chance of living, a chance that is nearly lost--

Your chance to own a heart and for your feelings not to die; Your chance to disperse beauty amidst the onslaught of pain, to understand the afflicted and empathize with them to the extent of the grief and injustice that had overtaken them;

Your chance to swallow patience as a means for survival, without sacrificing dignity; to cling onto the "need for dignity" and the need for your own share of personal dignity.

Your chance for an opportunity to an independent opinion, to work the mind and safeguard it from being confiscated, to conserve conscience, and to be dedicated to your work.

Your chance to search for the small joys, to create the desire to live, and to shape for yourself a full life amid the madness of death.

Your chance to not allow them to assassinate your dreams or take away from your pleasure, from the vastness of imagination, or from the amazement that comes with the search for knowledge. Your chance to know your identity as a human, and to not destroy it with power ideologies and politicized religions.

...

This is our chance to say to tyranny: No! Here amidst the flames of our homeland and not in the cold of exile.

(Abed Alsamad, 2015) [Translated by Ghada Alatrash]

We believe that such knowledge can only reside within a human lived experience, and most importantly, it is raw knowledge, one that is stripped from the political and the colonial, and is compacted with human feelings that are driven by the basic desire to live. Abed Alsamad (2014) further writes about the different layers of displacement within the Syrian Diaspora and how the 
word "displacement" takes on not one but a myriad of meanings that embody "degrees and levels" of pain and loss (para. 1). She explains that within the context of the Syrian war, "displacement" may refer to a temporary movement of a person (and her family) from one's own home to a safe building where they take refuge while waiting for the shelling to end-a temporary state that usually lasts a few hours. She then moves on to speak about the displacement that comes to be after loud speakers begin to sound off in the city warning for residents to clear out of their homes for their own safety, where people frantically head in search of a city within their country's border in which they can take refuge, a city that may be home to some relative and friends, "where you [as Syrians] thank God that you are still living in your own country ... [where] your children area able to continue their education in their new schools with the same school curriculum that they had begun [earlier in the year]" (para. 5). She then goes on to discuss yet another meaning of displacement, the one in which masses of Syrians look for refuge in a neighboring Arab country that speaks the same Arabic language (Lebanon, Egypt, Jordan or Iraq), unless the borders had become closed for entry-a displacement that teaches you "the art of smuggling human beings" (para. 6). And that is not all. Abed Alsamad adds yet another layer to the meaning of displacement, one that represents the bodies of Syrian Diaspora who have taken refuge in Turkey where "you [as Syrians] are shocked" by a Turkish Latin language and "if you address them [the Turks] in Arabic or another language, they answer, "No English"" (para. 9), and "where you [as a Syrian] find yourself placed in a refugee camp pleading "to a God in his sky: God, please do not send us rain here, or cold" (para. 12). The layers of meaning of displacement in Abed Alsamad's short article seem to have no end. Dignity for her Diasporic Syrian people is also a matter that she touches on and asks why is it that all governments - her country's as well as other host countries - continue to reject Syrians as if they were some sort of an insult. She then ends her article, as she began it, and again speaks of the meaning of displacement, writing,

Even the dictionary seems to mumble the meaning of 'Displacement' but is unable to disclose it fully. Displacement is: 'An absence from home for a long period of time.' The Displaced is: 'The faraway.' [Abed Alsamad exclaims]. Indeed, it is the 'faraway!' And it is the silence in all explanations and interpretations. As for 'refuge,' its definition is a predictor of its horror: It is the "fleeing out the country for political or other reasons." And for this is yet another level. (para. 21-22)

Trying to make sense of the feelings and emotions that are weaved into Abed Alsamad's article is a very difficult task, and, in our opinion, could not fully be understood unless lived as an experience. However, Abed Alsamad's narrative does offer an insight that, we feel, evokes an empathetic understanding, one that could not be delivered by any other lens but that of those living the Diasporic experience. It represents an account of a "painful site of spiritual injury ... a painful site of ungrievable loss (Butler, 1997), a place, a memory of suffering" (Simmons, 2012, p. 63).

\section{Conclusion}

It is our hope that the selected authors in this paper have offered new ways in which we may

Journal of Contemporary Issues in Education, 2020, 15(2), pp. 3-22. 
better know and understand what it means to be Syrian, and have come to challenge and disrupt some of the ontological and epistemological Orientalist, Eurocentric and colonial underpinnings that have historically defined the Syrian subject. The complex human experiences in the discussed narratives speak to many of the lived experiences of the Syrian Diaspora before and after the war. We find that such narratives are often dismissed, and perhaps at times are silenced, in our Western discourses, and as importantly, this gap in our knowledge of the Arab subject has contributed to a great deal of misunderstandings and misrepresentations. Our aim in writing this paper was to help fill in this gap as we (educators, employees, community organizations, policy makers) try to facilitate the process of integration for Syrian newcomers in Canada and beyond. To deliver a sense of Syrian identities and their experience, we bring into this discussion only a handful of the many voices of pre-Syrian-war writers and poets including Nizar Kabbani, Muhammad al-Maghut, Zakaria Tamer, Mamduh Adwan, Adonis and Nasib Arida. What we have selected of Syrian works in this paper speaks to two different topics: political dissent and the longing for return to a homeland. Furthermore, to capture a glimpse of a post-war written sentiment, we engage the voice of Syrian Novelist Najat Abed Alsamad (one of the authors of this paper) whose work was written from within the national borders of a war-torn Syria.

We will end by reminding our readers that the Syrian literary experience and the exploration of the Syrian sense of identity cannot possibly be presented through a single essay, nor through a limited selection of literary passages translated into English. Other works ought to be considered as we think of the exiled and diasporic Syrian identity, ones that also speak to their forced migration in search of a life that was unattainable in a homeland, as well as in quest of dignity and the very basic of human rights. What we offer in this essay is but a limited representation of an unlimited and exceptional literary realm that is offered by Syrians writers, poets and thinkers, and it is our hope that we will continue to fill in this gap as part of our responsibility as Syrian writers and academics in the West.

\section{References}

Abed Alsamad, N. (2014, April 5). Displacement. [My translation]. Annahar. Retrieved from http://newspaper.annahar.com/article/122732-النزوح

Abed Alsamad, N. (2015, January 17). You are alive then. [My translation]. Annahar. Retrieved from http://newspaper.annahar.com/article/206341-نص--أنت-حي-إذا-م

Abed Alsamad, N. (2016). If (G. Alatrash, Trans.). In E. Strang, N. Hunt, \& C. Chapman (Eds.), Dark mountain (10 ed.). Padstow, U. K.: The Dark Mountain Project 2016.

Adonis. (2010). Adonis selected poems (K. Mattawa, Trans.). New Haven, CT: Yale University Press.

Adwan, M. (2009). Misyaf. Retrieved from http://oakscoast.blogspot.ca/2015/09/blogpost_58.html

al-Maghut, M. (1987). Sa'akhūnu Wațanl : Hadayān fi al-ru'bi wa al-hurriyya [I will betray my homeland]. London: Riad El-Rayyes Books Ltd.

Alatrash, G. (2016). Stripped to the bone: Portraits of Syrian women. Ottawa, ON: Petra Books.

Arida, N. (n.d.). Take me back to Homs even if stuffed in a coffin [My translation]. Andalusiat.

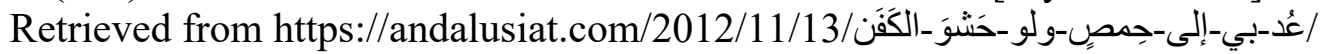

Butler, J. (1997). The psychic life of power: Theories in subjection. Stanford, Calif.: Stanford University Press.

Journal of Contemporary Issues in Education, 2020, 15(2), pp. 3-22. 
Césaire, A. (1995). Notebook of a return to my native land [Cahier d'un retour au pays natal] (M. Rosello \& A. Pritchard, Trans.). Newcastle upon Tyne, England: Bloodaxe Books. Chang, H. (2008). Autoethnography as method. Walnut Creek, Calif.: Left Coast ; Oxford : Berg [distributor].

Citizenship and Immigration Canada. (2017). \#WelcomeRefugees: Milestones and key figures. http://www.cic.gc.ca/english/refugees/welcome/milestones.asp

Clark, P. (2005). Mamdouh Udwan. The Guardian. Retrieved from https://www.theguardian.com/news/2005/jan/25/guardianobituaries.booksobituaries

Darwish, M. (2000). The Adam of two Edens. Syracuse, NY: Syracuse University Press

Darwish, M. (2013). Unfortunately, it was paradise: selected poems Berkley, CA: University of California Press.

Demeter, D. (2014). Homs - Old houses. Retrieved from http://www.syriaphotoguide.com/home/homs-old-houses-حمص_البيوت_القديمة/

Díaz, N. R. (2016). Against all odds: Defining a revolutionary identity in Syria. In A. Douai \& M. B. Moussa (Eds.), Mediated identities and new journalism in the Arab world: Mapping the "Arab Spring". UK: Palgrave Macmillan.

Eid, J. (2016). Wedding photos taken amid ruins in Homs, Syria are breathtaking. The Huffington Post Canada. Retrieved from http://www.huffingtonpost.ca/2016/02/09/wedding-photos-homs-syriaruins_n 9197282.html

Encyclopedia of Arabic Literature. (1998). (Vol. 1). New York: Routledge.

Foucault, M. (2007). The politics of truth. Los Angeles: Semiotext(e).

Foucault, M. (1980). Power/knowledge: Selected interviews and other writings 1972-1977. New York: Pantheon Books.

Government of Canada. (2019). Syrian Refugees - Monthly IRCC updates. https://open.canada.ca/data/dataset/01c85d28-2a81-4295-9c06-4af792a7c209

Hacker, M. (2012). Five texts by Zakaria Tamer. Jadaliyya. Retrieved from http://www.jadaliyya.com/pages/index/8330/five-texts-by-zakaria-tamer

Immigration, Refugees and Citizenship Canada (IRCC). (2018). Canada - Admissions of Syrian refugees by province/territory of intended destination, gender, age group and immigration category. Retrieved from https://open.canada.ca/data/en/dataset/01c85d282a81-4295-9c06-4af792a7c209

Kabbani, N. (1992). Works that are frowned upon. [My translation]. Beirut, Lebanon: Niazr Qabbani Publising House.

Kahf, M. (2000, January 1). Politics and Erotics in Nizar Kabbani's Poetry: From the Sultan's Wife to the Lady Friend. World Literature Today. Retrieved from https://www.thefreelibrary.com/Politics+and+Erotics+in+Nizar+Kabbani\%27s+Poetry\% $3 \mathrm{a}+$ From + the + Sultan $\% 27 \mathrm{~s} . .$. -a062655944

Kahf, M. (2001, March 22). The silence of contemporary Syrian literature. World Literature Today, pp. 225-236. Retrieved from go.galegroup.com/ps/i.do? $\mathrm{p}=\mathrm{AONE} \& \mathrm{sw}=\mathrm{w} \& \mathrm{u}=\mathrm{ucalgary} \& \mathrm{v}=2.1 \& \mathrm{id}=\mathrm{GALE} \%$ 7CA 8050 $0168 \& \mathrm{it}=\mathrm{r} \& \mathrm{asid}=3 \mathrm{ba} 65 \mathrm{fc} 3108 \mathrm{bdce} 674 \mathrm{a} 60981271302 \mathrm{db}$

Kincheloe, J. (2004). Introduction: The power of the bricolage: Expanding research methods. In J. Kincheloe \& K. S. Berry (Eds.), Rigour and complexity in educational research: Conceptualizing the bricolage (pp. 1-22). Maidenhead: Open University Press. 
Lincoln, Y. S., \& Guba, E. G. (2000). Paradagmatic controversies, contradictions, and emerging confluences. In N. K. Denzin \& Y. S. Lincoln (Eds.), The Sage handbook of qualitative research (2nd ed., pp. 163-188). Thousand Oaks, CA: Sage.

Mahmud, S. (2012). Symbols of the Syrian opposition. BBC News. Retrieved from http://www.bbc.com/news/world-middle-east-16988927

Pearlman, W. (2017, January 30). I interviewed 300 Syrian refugees. They are far from a security threat. The Washington Post. Retrieved from https://www.washingtonpost.com/news/monkey-cage/wp/2017/01/30/i-interviewed-300syrian-refugees-they-are-far-from-a-security-threat/?utm_term=.d687ce721655

Said, E. (1979). Orientalism (1st Vintage Books ed.). New York: Vintage Books.

Said, E. (1980, April 26). Isalm through Western eyes. The Nation. Retrieved from https://www.thenation.com/article/islam-through-western-eyes/

Said, E. (2002). Reflections on exile and other essays. Cambridge, Mass.: Harvard University Press.

Simmons, M. (2012). Politics of diaspora. ProQuest Dissertations and Theses, OISE/University of Toronto.

Thomas, E. E., \& Stornaiuolo, A. (2016). Restorying the self: Bending toward textual justice. Harvard Educational Review, 86(3), 313-338.

Treacher, A. (2003). Reading the other: Women, feminism, and Islam. Studies in Gender and Sexuality, 4(1), 59-71.

Watt, H., Blair, D., \& Sherlock, R. (2013, September 3). Syria's refugee crisis the 'humanitarian calamity' of the century, says UN. The Telegraph. Retrieved from http://www.telegraph.co.uk/news/worldnews/middleeast/syria/10282089/Syrias-refugeecrisis-the-humanitarian-calamity-of-the-century-says-UN.html

Xie, S. (1999). Rethinking the identity of cultural otherness: The discourse of difference as an unfinished project. In R. McGillis (Ed.), Voices of the other: Children's literature and the postcolonial context (pp. 1-17). London: Routledge. 